\title{
QALBUN SALIM PERSPEKTIF TAFSIR IBNU KATSIR
}

\author{
Ahmad Haromaini \\ Universitas Islam Syekh-Yusuf Tangerang \\ aharomaini@unis.ac.id. \\ Abdulrachman \\ Universitas Mercubuana Jakarta \\ a_rachman@mercubuana.ac.id
}

\begin{abstract}
Abstrak
Hati merupakan inti dari tubuh manusia, baik dan buruknya sangat berpengaruh dari kondisi hati seseorang. Literatur penafsiran mengenai hati banyak ditemukan di beberapa kitab tafsir, salah satunya adalah Ibnu Katsir dalam kitab Tafsir al-Qur'an al-'Azhim. Bagaimanakah sikap Ibnu Katsir dalam menafsirkan kata tersebut? Adakah kecenderungan konsistensi pengambilan sumber rujukan yang dilakukan ketika menafsirkan? Penelitian ini dilakukan dengan mengambil pembahasan secara tematik dan mengambil satu sumber data penelitian. Hasil penelitian menyebutkan bahwa adanya konsistensi dari tokoh yang menjadi sumber rujukan dalam penafsiran qalbun salim serta pemaknaan qalbun salim diartikan dengan selamat dari kotoran dan kemusyrikan dan yang bersih, hati yang hanya dimiliki oleh orang-orang yang beriman.
\end{abstract}

\section{Kata Kunci: Ibnu Katsir, Hati, Qalbun Salim}

\begin{abstract}
The heart is the core of the human body, good and bad are very influential on the condition of one's heart. Interpretive literature regarding the heart is found in several tafsir books, one of which is Ibn Kathir in the Tafsir al-Qur'an al-'Azhim. What is Ibn Kathir's attitude in interpreting the word? Is there a tendency to consistency in taking reference sources when interpreting? This research was conducted by taking a thematic discussion and taking one research data source. The result of the research states that the consistency of the figures who are the sources of reference in the interpretation of qalbun salim and the meaning of qalbun salim is defined as being safe from dirt and polytheism and a clean heart, which only belongs to those who believe.
\end{abstract}

\section{Keywords: Ibn Kathir, Heart, Qalbun Salim}

\section{A. Pendahuluan}

Istilah qalb dalam beberapa literatur dapat diterjemahkan dengan istilah hati, ${ }^{1}$

${ }^{1}$ Kementerian Agama RI. menerjemahkan kata qalb dengan hati. Penerjemahan tersebut dapat disaksikan dari terjemahan al-Qur'an yang diterbitkan di saat menerjemahkan dan menjelaskan tentang makna qalb dari QS. Al-Baqarah [2]: 7 dan 10. Lihat Kementerian Agama RI. Al-Qur'an dan Terjemahnya, (Jakarta: Kementerian Agama RI, 2012), h.3. heart, ${ }^{2}$ sinonim dari fu'ad. ${ }^{3}$ Sedangkan dalam teks al-Qur'an dapat dijumpai dalam

${ }^{2}$ Penerjemahan kata qalb dengan heart merujuk pada penerjemahan yang dilakukan oleh Muhammad Taqi al-Din al-Hilali dan Muhammad Muhsin Khan ketika menerjemahkan QS. AlBaqarah [2]: 7 dan 10. Lihat. Muhammad Taqi alDin al-Hilali dan Muhammad Muhsin Khan, Madinah. K.S.A.: King Fahd Complex For The Printing The Holy Qur'an1404 H.), hal. 4. Namun demikian tidak semua linguis menyebut kata heart 
beberapa terma yang dipahami sebagai kata yang memiliki makna hati, namun istilah-istilah tersebut tidak selalu bermuara pada satu pesan yang sama. Meskipun memiliki kemiripan (musytarak al-lafdzi $)^{4}$ tetapi memiliki referensi makna

merujuk hanya pada makna hati. Pada beberapa kamus, sebut saja yang ditulis Jhon M. Echols dan Hasan Shadily menerjemahkan kata heart tidak merujuk pada makna hati melainkan jantung ketika pada frasa-frasa tertentu seperti heart disease yang dimaknai dengan penyakit jantung atau to have a heart attack sebagai kalimat dengan terjemah terkena serangan jantung. Namun di samping makna jantung kata heart bisa dipahami sebagai hati seperti dalam kalimat "you are one after my own heart, yang dipahami dengan kamulah yang menyenangkan hatiku. Lihat. Jhon M. Echols dan Hasa Shadily, Kamus Inggris Indonesia, (Jakarta: Gramedia, 2005), cet. xxvi, h. 294.

${ }^{3}$ Attabik 'Ali dan Ahmad Zuhdi Muhdhar menyinonimkan kata qalb dengan fu'ad lalu diterjemahkan dengan hati, lubuk hati dan jantung. Penerjemahan lain dari akar kata qalb dalam bentuk kata jadian diterjemahkan dengan beberapa makna, seperti; yang murni, inti, esensi, bagian dalam, pusat , bagian tengah, tengah-tenga. Lihat Attabik 'Ali dan Ahmad Zuhdi Muhdhar, Kamus al- 'Ashri, (Yogyakarta: Multi Karya Grafika), cet. ke-VIII, h. 1467.

${ }^{4}$ Musytarak lafdzi merupakan lafadz ragam kata namun memiliki kemiripan makna satu dengan yang lainnya. Diskursus soal isytirak al-lafdzi menemukan ruang diskusi dan meninggalkan polemik di kalangan para linguis. Dari perdebatan tersebut menimbulkan madzhab-madzhab dalam bahasa Arab. Polemik para linguis Arab mempersoalkan mengenai diakui dan tidaknya mengenai lafadz yang berragam namun memiliki makna yang sama. Perdebatan tersebut dicatat dalam studi yang dikembangkan oleh Muhammad Sharur dalam studi ilmu-ilmu al-Qur'an kontemporer. Penolakan terhadap sinonim atau asinonimitas dipelopori oleh Ibnu Faris dengan hasil karya ilmiah linguistik dalam buku Miqyas alLughah, Ibnu Faris dengan tegas menolak sinonim. Sikap asinonimitas Ibnu Faris kemudian diteruskan dan diikuti oleh Muhammad Sahrur ulama kontemporer yang menulis buku "Al-Kitab wa alQur'an, Qira'ah Mu'ashirah. Lihat. Muhammad Shahrur, Prinsip dan Dasar Hermeneutika AlQur'an Kontemporer, terj. Sahiron Syamsuddin, (Yogyakarta: Elsaq, 2004), cet. ke-1, h. 57. yang berbeda. Demikian kehebatan alQur'an mengomunikasikan informasinya kepada khalayak pembaca (mukhathab, yang diajak bicara) sehingga tampaklah keluhuran bahasa al-Qur'an.

Penyebutan kata hati dalam bentuk qalb oleh al-Qur'an sudah disinggung sejak awal di saat menjelaskan kriteria relasi manusia bertuhan, tepatnya pengungkapan karakter orang-orang yang tidak beriman kepada Allah swt. Pada kesempatan tersebut, al-Qur'an mengungkapkan posisi orang kafir ${ }^{5}$ dan orang munafik. ${ }^{6}$ Kedua kelompok tersebut dijelaskan oleh al-Qur'an dengan gambaran keadaan hatinya yang tertutup ${ }^{7}$ dan memiliki penyakit.Para sufi menyebut qalb sebagai ekspresi yang disampaikan ruhani dalam merespon bentuk-bentuk keadilan. ${ }^{8} \quad$ 'Abd al-Karim al-Jilli mengungkapkan qalbu yang dimaksud merupakan nur azali dan bersifat rahasia yang tinggi dan dimanifestasikan dalam bentuk wujud alam semesta. ${ }^{9}$ Sehingga ia dapat disebut sebagai organ rohani yang tidak berwujud, abstrak, immateri namun peran dan fungsi yang dimiliki oleh hati ini sangat penting bagi manusia. ${ }^{10}$ Seperti halnya organ tubuh manusia yang tampak di luar (terlihat olehnya dan orang yang di luarnya) dapat melakukan dan mengerjakan setiap tindakan yang

${ }^{5}$ QS. Al-Baqarah [2]:6-7.

${ }^{6}$ QS. Al-Baqarah [2]: 8-10.

${ }^{7}$ Al-Maraghi menyebut tertutupnya hati mereka merupakan sunatullah, ketentuan Allah swt. akibat dari komitmennya dalam kekufuran. Lihat. Ahmad Musthafa al-Maraghi, Tafsir al-Maraghi, terj. K. Anshori Umar Sitanggal dkk., (Semarang: Toha Putra, 1992), cet. ke-2, jil. K-2, h.71.

${ }^{8}$ Ashim Ibrahim Al-Kayyali, Al-Hikam Ibnu 'Athaillah, terj. M. Tatam Wiajaya,(Jakarta, Qaf Media, 2018), cet. ke-1, h.297.

${ }^{9}$ Ashim Ibrahim Al-Kayyali, Al-Hikam Ibnu 'Athaillah..., h. 298.

10 Kemetrian Agama RI, Al-Qur'an dan Tafsirnya, (Jakarta: Kementerian Agama RI, 2012), cet. ke-1, jil. 7, h. 99 . 
mengharuskan ragawi manusia melaksanakannya, seperti berjalan, memegang, melihat, makan dan lain-lain. Mengharuskan seseorang yang melakukannya menggunakan kaki, tangan, mata, mulut dan yang lainnya, yang semua itu tampak dan kasat mata. Namun perbuatan-perbuatan hati seperti cinta kepada Allah, ikhlas, tawakkal, ridha, dan sejenisnya, merupakan tindakan yang sulit untuk dilihat (bahkan tidak mungkin). Tetapi bukan berarti ia tidak dibutuhkan atau ditinggalkan bahkan itu menjadi perkara yang diperintahkan yang harus dimiliki oleh setiap orang baik para cendekia maupun orang umum. ${ }^{11}$

Sebagai sebuah frasa yang disebutkan dalam al-Qur'an-setidaknya dua kali disebutkan-frasa qalbun salim menarik untuk dilakukan penelitian. Penelitian akan jauh lebih menarik bila dilakukan dalam mengeksplorasi penafsiran yang dilakukan oleh seorang mufassir dalam menjelaskan kata-kata tersebut serta relevansinya dengan ayatayat lain yang menjadi kajian kata atau frasa yang sama pada ayat-ayat lain. Apakah kecenderungan penafsiran seorang mufassir hanya terfokus pada satu ayat yang dijelaskan tanpa mengaitkan ayat lain dengan kemiripan kata yang sama untuk ditafsirkan, atau memiliki penafsiran yang sama meskipun terdapat pada ayat yang berbeda disebabkan konteks dan pembahasan teks terfokus pada persoalan atau tokoh yang sama? Penelitian ini menarik untuk dijelaskan untuk mengetahui bagaimana seorang mufassir menafsrikan dua frasa yang sama.

\section{B. Profil Singkat Ibnu Katsir}

Ibnu Katsir merupakan nama populer yang dikenal oleh para pengkaji tafsir al-

\footnotetext{
${ }^{11}$ Muhammad Ibnu Taimiyyah, Risalah Tasawuf Ibnu Taimiyyah, (terj. Anis Masykhur, (Hikmah, Jakarta: 2002), set. Ke-1, h 1.
}

Qur'an. Nama lengkap yang disandang mufassir ini adalah Abu al-Fida Isma'il ibn 'Umar ibnKatsir ibn Dhaw' ibn Katsir ibn Dar' al-Qursi. ${ }^{12}$ Beliau berasal dari Damaskus kota yang dikenal berada di wilayah teritorial negeri Suriah, hal itu dibuktikan dengan pencatunman alDimasyqi pada nama lengkap yang dituliskan dalam kitab tafsirnya. ${ }^{13}$ Beliau juga dikenal sebagai ulama dengan madzhab fiqh Syafi'i serta seorang ahli hadits. ${ }^{14}$

Manna' al-Qaththan menyebut Ibnu Katsir dilahirkan pada tahun $705 \mathrm{H}^{15}$ Sedangkan berdasarkan informasi dari kitab tafsir Ibnu Katsir, beliau lahir pada tahun $701 \mathrm{H}^{16}$ Ia dikenal selain sebagai mufasir, juga sebagai ahli hadits yang faqih. $^{17}$

Ahmad Syurbasi mengutip pendapat Sayyid Ahmad Khalil mengelompokkan Tafsir Ibnu Katsir ke dalam kelompok tafsir atsari, tafsir riwayah, atau tafsir naqli. ${ }^{18}$ Periode tafsir dalam jenis ini dikelompokka demikian disebabkan sumber rujukkan penafsiran terdiri dari lima sumber yang meliputi al-Qur'an, alHadits, riwayat sahabat, pendapat tabi'in, tabi' al-tabi' in dan sumber rujukkan yang

${ }^{12}$ Al-Hafidz Ibn Katsir, Tafsir al-Qur'an al'Azhim, (Kairo: Dar al-Hadits, 2003), jil.1, cet. ke1, h. 5 .

${ }^{13}$ Al-Hafidz Ibn Katsir, Tafsir al-Qur'an al'Azhim..., h.5.

${ }^{14}$ Manna' Khalil al-Qaththan, Mabahits $F i$ 'Ulum al-Qur'an, (Riyadh, Mansyurat al-'Ashr alHadits, tt), cet. ke-3, h. 386.

${ }^{15}$ Manna' Khalil al-Qaththan, Mabahits Fi 'Ulum al-Qur'an..., h. 386.

16 Al-Hafidz Ibn Katsir, Tafsir al-Qur'an al'Azhim..., h.5.

${ }^{17}$ Manna' Khalil al-Qaththan, Mabahits Fi 'Ulum al-Qur'an..., h. 386.

18 Ahmad Syurbasi, Study Tentang Sejarah Perkembangan Tafsir al-Qur'an al-Karim, terj. Zufran Rahman, (Jakarta: Kalam Mulia, 1999), cet. ke-1, h. 239. 
dikemukakan dari kelompk ahl al-kitab atau yang populer dengan israilliyyat. ${ }^{19}$

Kitab tafsir yang disusun Ibnu Katsir oleh Syaikh Muhammad Rasyid Ridha disebut sebagai kitab tafsir yang sangat populer karena penulisnya mampu menghadirkan riwayat-riwayat yang disampaikan oleh para ulama salaf serta kepandaian penulis dalam menafsirkan makna-makna ayat disertai dengan hukumhukumnya namun tidak terjebak dalam membahas kaidah-kaidah kebahasaan dan stilistika lagi mendalam yang umumnya banyak dilakukan oleh para ulama tafsir. ${ }^{20}$

\section{Qalbun Salim perspektif Tafsir Ibnu Katsir}

Diskursus mengenai kondisi hati manusia, Al-Ghazali pernah menyebutkan bahwa hati yang dimiliki manusia memiliki tiga keadaan yang terdapat dalam hatinya, mulai dari hati yang sahih, yakni hati yang selamat atau bisa disebut juga sebagai qalbun salim. Kondisi hati yang seperti ini, menurutnya akan dapat bertemu dengan Allah swt. ${ }^{21}$ kemudian hati yang mati, mayyit, ia mengeras dan membatu yang berdampak pada mengeraknya hati yang dimilikinya. Keadaan demikian disebabkan begitu banyaknya dosa yang diperbuatnya dan hati yang sakit maridh, ia dikenal sebagai hati yang masih bercampurnya keimanan, kebaikkan, ibadah dengan kemaksiatan yang dilakukannya. $^{22}$

Frasa qalbun salim dalam bentuk kata sifat setidaknya disebutkan dua kali

\footnotetext{
${ }^{19}$ Ahmad Syurbasi, Study Tentang Sejarah...h. 239.

${ }^{20}$ Manna' Khalil al-Qaththan, Mabahits Fi 'Ulum al-Qur'an..., h. 386.

${ }^{21}$ Muhammad ibn Ibrahim, Syarh al-Hikam, (Haramain, Indonesia:tt), juz. Ke-1, h, 42

${ }^{22}$ Muhammad ibn Ibrahim, Syarh al-Hikam, (Haramain, Indonesia:tt), juz. Ke-1, h, 42
}

dalam mushaf al-Qur'an. ${ }^{23}$ Dua ayat tersebut terdapat pada QS. Al-Syu'ara [26]: 89.

$$
\text { إلاًّا مَنْ أَتَى أللَّهَ بِقَلْبِ سَلِيمِ }
$$

"Kecuali orang-orang yang menghadap Allah dengan hati yang bersih". 24

Ayat di atas menjadi penghujung penjelasan yang membahas perihal doa yang dipanjatkan nabi Ibrahim a.s. yang memiliki relevansi dengan ayat sebelumnya yang menjelaskan mengenai nabi Ibrahim pujiannya kepada Allah swt. dengan mengemukakan berbagai sifatnya berupa pemberi hidayah, makan dan minum, yang menyembuhkan penyakit, yang menghidupkan dan mematikan serta yang memberi ampunan. ${ }^{25}$ Sedangkan pada ayat lain, frasa qalbun salim terdapat pada QS. al-Shaaffat [37]: 84. Di mana Allah swt. berfirman:

$$
\text { إذذْ جَآَ رَبَّهُ بِقَلَبِ سَلِيمرِ }
$$

"(Ingatlah), Ketika ia datang kepada Tuhannya dengan hati yang suci”.

Bila dipahami secara etimologis, kata qalb dapat dipahami sebagai wadah yang dapat digunakan oleh manusia untuk memperoleh pengetahuan. $^{26}$ Karena dengan hati yang dimiliki manusia bisa mendapatkan pengetahuan yang inginkannya. Pengetahuan bagi manusia merupakan hal yang sangat penting. Pengetahuan dapat membimbing manusia memperoleh apa yang dibutuhkannya dan tentunya dapat membantunya menjalankan misi kemanusiaan sesuai dengan apa yang diamanahkan Tuhan kepadanya. Manusia

${ }^{23}$ Faidhullah al-Hasani al-Maqdisi, Fath alRahman, (Bandung: Maktabah Dahlan, tt), cet. ke1, h. 367.

${ }^{24}$ Kementerian Agama RI, AL-Qur'an dan Tafsirnya..., h. 98.

${ }_{25}^{25}$ Kementerian Agama RI, AL-Qur'an dan Tafsirnya..., h. 99.

26 Kementerian Agama RI, Al-Qur'an dan Tafsirnya, jil. 7, h. 99. 
juga dapat disebut sebagai makhluk idealistis, tinggi cita-cita dan pemikirannya. $^{27}$

Sedangkan kata salim bila diterjemahkan secara etimologis sebagai selamat, sehat, tidak sakit dan sebagainya. ${ }^{28}$ Sehingga bila bila kata qalb digabungkan dengan kata salim sehingga menjadi frasa qalbun salim dapat diterjemahkan sebagai hati yang tidak sakit, sehingga pemiliknya senantiasa merasa tenang, terhindar dari keraguan dan kebimbangan dan hati yang dimilikinya tidak angkuh, benci, dengki, dendam, dan setiap sifat tercela lainnya tidak akan menjadi sifat yang dimiliki oleh mereka yang memiliki qalbun salim. $^{29}$ Atau dengan kata lain, hatinya selamat dari kehendak dirinya sendiri. ${ }^{30}$

Bagi syekh Ihsan Muhammad Dahlan Jampes, hati memiliki posisi yang sangat penting bagi tubuh manusia. Beliau menyebut hati merupakan anggota keempat dalam empat rangkaian anggota tubuh yang dimiliki manusia, meskipun pada urutan keempat kedudukannya menjadi penting disebabkan sebagai asal, pokok dari keseluruhan. ${ }^{31}$

Pada beberapa literatur tafsir, qalbun salim merupakan satu rangkaian dalam kelompok ayat yang menjelaskan mengenai doa nabi Ibrahim a.s. ${ }^{32}$ karena

${ }^{27}$ Murtadha Muthahari, Manusia dan Alam Semesta, (Jakarta: Penerbit Lentera, 2002), cet. ke1, h. 3 .

${ }^{28}$ Kementerian Agama RI, AL-Qur'an dan Tafsirnya..., jil. 8, h. 293.

${ }^{29}$ Kementerian Agama RI, AL-Qur'an dan Tafsirnya..., jil. 8, h. 293.

${ }^{30}$ Al-Imam Abi Al-Qasim 'Abd Al-Karim Ibn Hawazin 'Abd Al-Malik al-Qusyairi, Tafsir alQusyairi, (Bairut: Dar al-Kutub al-'Ilmiyyah, 2007), jil. 2, cet. ke-2, h. 402-403.

${ }^{31}$ Syaikh Ihsan Muhammad Dahlan alJampesy al-Kadiri, Siraj al-Thalibin, (Beirut: dar el-Fikri, 1955), cet. ke-1, jil. 2, h. 44.

${ }^{32}$ Salah satu yang mengelompokkan ke dalam do'a nabi Ibrahim a.s. adalah tafsir yang dalam mushaf al-Qur'an frasa ini disebut dua kali dan keduanya tentang nabi Ibrahim a.s. pada permulaan menjelaskan tentang doa yang dipanjatkan yang berisikan ilmu, masuk dalam kategori orang-orang salih, memiliki tutur kata yang baik, pewaris surga, permohonan ampunan bagi kedua orang tua, tidak ingin dihinakan di hari kebangkitan, ${ }^{33}$ namun pada ayat yang lain berkenaan tindakan nabi Ibrahim sebagai penghancur berhala.

Ibnu Katsir dalam menafsirkan kata qalbun salim yang terdapat dalam dua ayat ini tidaklah memiliki perbedaan yang sangat signifikan. Bahkan dapat dikatakan sangat sama, baik yang terdapat dalam QS. Al-Syu'ara [26]: 89 dan QS. Al-Shaaffat [37]: 84. Sumber rujukan yang dijadikan penafsiran pun sama di antara dua ayat tersebut, yakni Ibnu Katsir mengutip

disampaikan oleh Kementerian Agama RI yang terbit tahun 2012. Tafsir ini mengelompokkan QS. Al-Syu'ara [26]: 83-89 sebagai kelompok ayat tentang do'a nabi Ibrahim a.s. Lihat Kementerian Agama RI, Al-Qur'an dan Tafsirnya..., hal. 98. Namun ada juga tafsir yang tidak mengelompokkannya ke dalam satu bahasan khusus melainkan disajikan dalam penjelasan tafsir yang mengulas satu persatu dari ayat-ayat suci al-Qur'an, sebut saja tafsir al-Qur'an yang ditawarkan oleh alImam Abi al-Qasim 'Abd al-Karim ibn Hawazin 'Abd al-Malik al-Qusyairi atau biasa disapa dengan tafsir al-Qusyairi beliau lebih menjelaskan ayatayat al-Qur'an ayat per ayat. Lihat al-Imam Abi alQasim 'Abd al-Karim ibn Hawazin 'Abd al-Malik al-Qusyairi, Tafsir al-Qusyairi, (Bairut: Dar alKutub al-'Ilmiyyah, 2007), jil. 2, cet. ke-2, hal. 402-403. Akan tetapi Ibnu Katsir memiliki kesamaan dengan beberapa tafsir yang ditawarkan oleh para mufassir yang tetap menjadikan rangkaian penjelasan ayat tentang qalbun salim merupakan satu kelompok dengan 6 ayat sebelumnya yang merupakan satu kesatuan sebagai do'a yang dipanjatakn oleh nabi Ibrahim a.s. Lihat Ibnu Katsir, Tafsir al-Qur'an al- 'Azhim, jil. 2, h. 416.

${ }^{33}$ Kemetrian Agama RI, Al-Qur'an dan Tafsirnya..., h. 98 . 
pendapat dari sahabat Ibnu 'Abbas, Muhammad ibn Sirin, dan al-Hasan. ${ }^{34}$

Qalbun salim dimaknai dengan selamat dari kotoran dan kemusyrikan. Kemudian beliau juga mengutip pendapat Muhammad ibn Sirin yang menyebutkan bahwa maksud dari frasa tersebut bahwa qalbun salim adalah hati yang mengetahui bahwa Allah swt. adalah benar, hari kiamat pasti akan datang dan tidak boleh ada keraguan di dalamnya dan Allah swt. akan membangkitkan manusia dari dalam kubur. ${ }^{35}$ Keimanan menjadi kunci bagi hati yang bersih, suci dari kotoran-kotoran kemusyrikan dan kemunafikan. Dengan dasar pengetahuan atas kebenaran ajaran Allah swt. melandasi keimanan seseorang kepada-Nya. ${ }^{36}$ Pengetahuan bermanfaat yang dimilikinya mampu mengantarkan dia bagaimana membedakan yang benar dengan yang salah, beriman kepada Allah swt. dan kepada Rasul-Nya, apa yang diwahyukan kepada nabi-Nya adalah wahyu yang bersumber dari-Nya, maka hati yang telah tunduk dan patuh kepada Allah swt. maka hatinya akan mendapatkan petunjuk dari Allah swt. yang akan membimbingnya di dunia dan akhirat serta mengantarkannya ke tingkatan surga dan membebaskannya dari siksa api neraka. ${ }^{37}$

Selain itu Ibnu Katsir sepakat dengan apa yang disebut oleh Sa'id ibn alMusayyab yang menyebut qalbun salim merupakan hati yang bersih, hati yang dimiliki oleh orang-orang yang beriman. Alasan mendasar tersebut disebabkan bahwa hati orang-orang kafir dan munafik merupakan hati yang sakit sesuai dengan firman Allah swt. "di dalam hati-hati

\footnotetext{
${ }^{34}$ Al-Hafidz Ibn Katsir, Tafsir al-Qur'an al'Azhim..., jil 3. h.417 dan Jil. 4. h. 17..

${ }^{35}$ Al-Hafidz Ibn Katsir, Tafsir al-Qur'an al'Azhim..., hal.417.

${ }^{36}$ QS. Al-Hajj [22]:54.

${ }^{37}$ Al-Hafidz Ibn Katsir, Tafsir al-Qur'an al'Azhim..., Jil. 3, h.285..
}

mereka terdapat penyakit. ${ }^{38}$ Penyakit yang diderita orang-orang munafik menurut Ibnu Katsir dalam bentuk keraguan. Penyakit yang diderita mereka bukanlah penyakit fisik melainkan penyakit yang diderita dalam persoalan agama. ${ }^{39}$

Penyakit-penyakit yang diderita ${ }^{40}$ itu dalam bentuk keraguan, kemusyrikan, kekafiran, dan kemunafikan. ${ }^{41}$ sebagai contoh perilaku orang musyrik seperti kebahagiaannya dengan kemusyrikan yang ditampilkannya dan meyakini bahwa yang demikian adalah sebuah kebenaran padahal sikap seperti itu merupakan bersumber dari setan yang menggodanya. Oleh sebab itu, orang-orang musyrik memiliki hati yang keras. $^{42}$

Penyakit yang diderita akibat dari kemusyrikan kepada Allah swt. adalah ditanamkannya rasa takut ke dalam hatihati mereka. ${ }^{43}$ Bahkan al-Jazairi menyebutkan bahwa yang ditanamkan bukan sekedar rasa takut lebih dari itu akibat dari kekalahan (perang) dan hal-hal yang tidak disukainya. ${ }^{44}$ Berkenaan dengan rasa takut yang ditanamkan kepada orangorang kafir, nabi Muhammad saw. menyampaikan beberapa keistimewaan yang dimilikinya berkat pemberian Allah swt. yang tidak diberikan kepada nabi-nabi sebelumnya. Ibnu Katsir menyebutkan keistimewaan-keistimewaan nabi Muhammad saw. dengan mengutip beberapa riwayat hadits dalam tafsirnya, salah satunya adalah: "Aku diberikan lima

\footnotetext{
${ }^{38}$ Al-Hafidz Ibn Katsir, Tafsir al-Qur'an al'Azhim..., h.417.

${ }^{39}$ Al-Hafidz Ibn Katsir, Tafsir al-Qur'an al'Azhim..., jil.1, h.65.

${ }^{40}$ QS. Al-Hajj [22]: 53-54.

41 Al-Hafidz Ibnu Katsir, Tafsir al-Qur'an al-'Azhim..., jil. 3, h. 285.

${ }^{42}$ Al-Hafidz Ibnu Katsir, Tafsir al-Qur'an al-'Azhim..., jil. 3, h. 285.

${ }^{43}$ QS. Ali-Imran [3]: 151.

44 Abi Bakar Jabir al-Jazairi, Aysar alTafasir, (Madinah: Maktabah al-'Ulum wa alHikam, 2003), jil. 1, cet. ke6, h. 184.
} 
hal yang sebelumnya tidak pernah diberikan kepada nabi-nabi sebelumku, aku ditolong dari rasa takut sepanjang bulan, bumi dijadikan masjid dan suci, dihalalkan harta ghanimah, diberikan syafa'at, nabi sebelumku diutus khusus kepada kaumnya sedangkan aku diutus untuk seluruh manusia". 45

Riwayat di atas menegaskan keistimewaan nabi Muhammad saw. yang diberkati oleh Allah swt. Beberapa keistimewaan yang tidak dimiliki oleh nabi-nabi sebelumnya. Beliau tidak diliputi rasa takut yang siapa saja dapat merasakan hal demikian bila terjadi sesuatu yang menimpanya. Bahkan berkenaan dengan ayat di atas, Ibnu Katsir menyebutkan bahwa Abu Sufyan dilemparkan ke dalam hatinya rasa takut. ${ }^{46}$

Rasa takut yang dialami oleh orangorang kafir adalah kekhawatiran, kegelisahan, maupun kepanikan. Sehingga dengan kondisi demikian memudahkan orang-orang beriman untuk membunuh dan mengalahkan mereka dalam peperangan. ${ }^{47}$ Posisi hati yang tertanam rasa takut mampu memudarkan konsentrasi lawan, fokus perlawanan yang mereka miliki menjadi terbelah, sasaran yang mereka targetkan pun menjadi sangat tidak terukur yang pada imbasnya membuat mereka dapat ditaklukkan dan kekalahan menjadi predikat yang mereka sandang di medan peperangan. Keadaan demikian diyakini sebagai pertolongan dari Allah swt. karena Allah swt. telah menyibukkan mereka dalam kekafiran yang dilakukannya. Mereka sudah melakukan kemusyrikan dengan menyembah Allah swt. namun

${ }^{45}$ Ibnu Katsir, Tafsir al-Qur'an al- 'Azhim..., jil. 1, h. 505 . jil. 1 , h. 505 .
${ }^{47}$ Abi Bakar Jabir al-Jazairi, Aysar al- Tafasir..., h. 184.

masih membarengkannya dengan Tuhan lain secara bersamaan. ${ }^{48}$

Sebagai salah satu upaya menghindari hal-hal demikian yang berdampak pada hati manusia, maka sebaiknya perlu dilakukan perbaikanperbaikan hati atau bisa juga disebut dengan cara melakukan rekonsiliasi hati. Rekonsiliasi hati ditempuh dengan keimanan, ilmu dan pengetahuan. ${ }^{49}$ Ilmu maupun pengetahuan menjadi penting bagi manusia. Pengetahuan membantu manusia untuk menemukan bagaimana ia mengetahui kewajibannya dan menuntaskan tugasnya sebagai manusia yang dibebankan dalam memakmurkan bumi. $^{50}$ Keunggulan ilmu pengetahuan yang dimilikinya, menjadikan manusia menjadi lebih istimewa dibanding dengan makhluk Allah swt. lainnya. ${ }^{51}$

Ibnu Katsir menyebutkan bahwa alQur'an sebagai penyembuh bagi hati yang menderita penyakit-penyakit yang menjangkitinya. Penawar yang ditawarkan al-Qur'an sebagai pembebas dari berbagai jenis kekejian berupa keraguan dan ketidakjelasan suatu hal yang dapat mengganggu manusia. ${ }^{52}$ Namun penawar yang disajikan al-Qur'an menurut Ibnu Katsir tidak berlaku bagi semua manusia,

\footnotetext{
${ }^{48}$ Abi Bakar Jabir al-Jazairi, Aysar alTafasir..., jil. 1, h. 184.

49 Syaikh Ihsan Muhammad Dahlan alJampesy al-Kadiri, Siraj al-Thalibin..., h. 44.

${ }^{50}$ Ahmad Haromaini, Manusia dan Keharusan Mencari Tahu, Jurnal Pelita LPPM Universitas Islam Syekh-Yusuf Tangerang Vol. 18. No. 2 Edisi Juli-Desember 2018, diakses pada: http://ejournal.unis.ac.id/index.php/pelita/article/vie $\mathrm{w} / 50$

${ }^{51}$ Ahmad Haromaini, Manusia Makhluq Pembelajar, Jurnal Islamika Fakultas Agama Islam Universitas Islam Syekh-Yusuf Tangerang Vol. 12 No. 1 Edisi Januari-Juni 2018, diakses pada hari Selasa 18 Agustus 2020 pada: http://ejournal.unis.ac.id/index.php/ISLAMIKA/arti cle/view/405

${ }^{52}$ Al-Hafidz Ibn Katsir, Tafsir al-Qur'an al'Azhim..., jil. 2. h.417.
} 
ia hanya dikhususkan bagi mereka yang beriman kepada Allah swt. ${ }^{53}$

Bagi para pendusta al-Qur'an yang sering melontarkan tuduhannya dengan mengatakan bahwa al-Qur'an hanyalah cerita-cerita orang terdahulu, ${ }^{54}$ sebenarnya klaim yang mereka tuduhkan bertentangan dengan fakta yang sebenarnya, yakni sesungguhnya al-Qur'an adalah kalamullah dan wahyu-Nya yang diturunkan kepada nabi Muhammad saw. ${ }^{55}$ Selanjutnya Ibnu Katsir menyebut bahwa hati mereka telah tertutup disebabkan perbuatan dosa yang mereka lakukan. ${ }^{56}$

Oleh karena itu, menurut Al-Ghazali, hati dapat terhalang oleh persoalanpersoalan yang akan menutupinya dan menyebabkan ia menjadi sakit dan mati. Al-Ghazali menyebut penghalang hati itu adalah tabir (hijab) dalam bentuk kesenangan dan terrealisasi dalam hubuddunya, terlalu dalam mencintai kehidupan dunia. Merebaknya perbuatan dosa yang memicunya munculnya kotoran dan mencatatkan noktah hitam. ${ }^{57}$

Upaya-upaya yang perlu dilakukan dalam memiliki hati yang selamat, sahih tidak sakit apalagi mati perlu dilakukannya pendidikan hati yang maksimal. Seseorang harus mampu melakukan taubat kepada Allah swt., Bertaubat merupakan suatu tindakan kembali dari yang tidak baik menjadi baik, sikap taubat menjadi suatu hal yang disenangi Allah swt. ${ }^{58}$, bahkan Allah swt. Senang akan taubat

${ }^{53}$ Al-Hafidz Ibn Katsir, Tafsir al-Qur'an al'Azhim..., jil. 2. h. 417.

${ }^{54}$ QS. Al-Muthaffin [83]: 13.

55 Al-Hafidz Ibn Katsir, Tafsir al-Qur'an al'Azhim..., jil. 4. h.589.

${ }^{56}$ Al-Hafidz Ibn Katsir, Tafsir al-Qur'an al'Azhim..., jil. 4. h.589.

57 Al-Hafidz Ibn Katsir, Tafsir al-Qur'an al'Azhim..., jil. 4. h. 381.

58 Abi al-Husain Muslim, Shahih Muslim, (Dar el-Fikr, Bairut:tt), jilid. II, h. 592
hambaNya, ${ }^{59}$ oleh karena itu seorang hamba tidaklah boleh berputus asa untuk dapat meraih kasih sayang Allah, sebab kasih sayangNya mengalahkan kebencianNya. ${ }^{60}$ Selain bertaubat, qana'ah yakni, bersikap rela menerima pemberian Allah swt. Meskipun sedikit perlu untuk diterapkan. Kemudian Zuhud Dunia, menjalankan syari'at untuk meningkatkan taqwanya, memelihara sunnah rasul, baik dalam pengertian melaksanakan amalan atau ibadah sunnat maupun mencontoh budi pekerti nabi saw., dan tawakkal. ${ }^{61}$

Usaha-usaha tersebut menjadi mutlak untuk dilakukan mengingat hati merupakan poros, inti yang memiliki perhatian khusus dan utama dalam mendidiknya. Syaikh Ihsan Jampes menyatakan bahwa hati seperti pohon dan anggota-anggota lain adalah dahan. Dari pohon akan teraliri air ke dahan-dahan, baik dan buruknya dahan tergantung pada pohonnya. Seperti halnya baik dan buruknya mata, perut dan lisan menunjukkan baik dan buruknya hati yang dimilikinya. $^{62}$

\section{Penutup}

Ibnu Katsir merupakan mufasir terkenal yang menorehkan karya tafsir populer yang bernama Tafsir al-Qur'an al'Azhim. Dalam upaya penafsiran mengenai qalbun salim, beliau memiliki konsistensi dalam melakukan kerja tafsirnya, mulai dari konsistensi rujukkan sahabat dan tabi'in serta konsisten pada pemaknaan frasa qalbun salim. Sumber rujukkan dari sahabat, Ibnu 'Abbas menjadi sahabat yang ia rujuk dan ulama masyhur Ibnu Sirin yang begitu konsisten menjadi sumber

59 Abi al-Husain Muslim, Shahih Muslim.., h. 592 h. 595

${ }^{60}$ Abi al-Husain Muslim, Shahih Muslim...,

61 Muhammad Ibnu Taymiyyah, Risalah Tasawuf..., h. 9

62 Syaikh Ihsan Muhammad Dahlan alJampesy al-Kadiri, Siraj al-Thalibin..., h. 46-47 
penafsirannya dalam pemaknaan makna qalbun salim. Qalbun salim dimaknai dengan selamat dari kotoran dan kemusyrikan. Selain itu Ibnu Katsir menyebut qalbun salim merupakan hati yang bersih, hati yang hanya dimiliki oleh orang-orang yang beriman.

\section{DAFTAR PUSTAKA}

Abi Bakar Jabir al-Jazairi, Aysara alTafasir, (Maktabah al-'Ulum alHikam, Madinah:2003)

Abi al-Husain Muslim, Shahih Muslim, (Dar el-Fikr, Bairut:tt)

Muhammad bin Shalih al-Munajjid, Amalan Hati, terj. Oleh: Bahrun Abu Bakar, Lc. (Irsyad Baitussalam, Bandung: 2006).

Al-Imam Abi al-Qasim 'Abd al-Karim ibn Hawazin 'Abd al-Malik al-Qusyairi, Tafsir al-Qusyairi, (Bairut: Dar alKutub al-'Ilmiyyah, 2007)

Ashim Ibrahim Al-Kayyali, Al-Hikam Ibnu 'Athaillah, terj. M. Tatam Wijaya,(Jakarta, Qaf Media, 2018).

Ahmad Syurbasi, Study Tentang Sejarah Perkembangan Tafsir al-Qur'an alKarim, terj. Zufran Rahman, (Jakarta: Kalam Mulia, 1999)

Faidhullah al-Hasani al-Maqdisi, Fath alRahman, (Bandung: Maktabah Dahlan, tt)

Kemetrian Agama RI, Al-Qur'an dan Tafsirnya, (Jakarta: Kementerian Agama RI, 2012).

Muhammad Taqi al-Din al-Hilali dan Muhammad Muhsin Khan, Madinah. K.S.A.: King Fahd Complex For The Printing The Holy Qur'an, 1404 H.).

Muhammad Shahrur, Prinsip dan Dasar Hermeneutika

Al-Qur'an
Kontemporer, terj. Sahiron Syamsuddin, (Yogyakarta: Elsaq, 2004).Ahmad Musthafa al-Maraghi, Tafsir al-Maraghi, terj. K. Anshori Umar Sitanggal dkk., (Semarang: Toha Putra, 1992).

Muhammad Ibnu Taimiyyah, Risalah Tasawuf Ibnu Taimiyyah, (terj. Anis Masykhur, (Hikmah, Jakarta: 2002).

Manna' Khalil al-Qaththan, Mabahits Fi 'Ulum al-Qur'an, (Riyadh, Mansyurat al-'Ashr al-Hadits, $t \mathrm{t})$

Murtadha Muthahari, Manusia dan Alam Semesta, (Jakarta: Penerbit Lentera, 2002

Syaikh Ihsan Muhammad Dahlan alJampesy al-Kadiri, Siraj al-Thalibin, (Beirut: dar el-Fikri, 1955)

Jhon M. Echols dan Hasa Shadily, Kamus Inggris Indonesia, (Jakarta: Gramedia, 2005). Attabik 'Ali dan Ahmad Zuhdi Muhdhar, Kamus al'Ashri, (Yogyakarta: Multi Karya Grafika, tt).

Ahmad Haromaini, Manusia dan Keharusan Mencari Tahu, Jurnal Pelita LPPM Universitas Islam Syekh-Yusuf Tangerang Vol. 18. No. 2 Edisi Juli-Desember 2018, diakses pada:

http://ejournal.unis.ac.id/index.php/p elita/article/view/50

Ahmad Haromaini, Manusia Makhluq Pembelajar, Jurnal Islamika Fakultas Agama Islam Universitas Islam Syekh-Yusuf Tangerang Vol. 12 No. 1 Edisi Januari-Juni 2018, diakses pada hari Selasa 18 Agustus 2020 pada:

http://ejournal.unis.ac.id/index.php/I SLAMIKA/article/view/405

Muhammad ibn Ibrahim, Syarh al-Hikam, (Haramain, Indonesia:tt) 
